\title{
Effect of feed supplemented exogenous bacteria, Lactobacillus sporogenes on the growth and body composition of Cirrhinus mrigala fingerlings
}

\author{
Laxmi Prasad* and P. V. Rangacharulu \\ College of Fisheries, Narendra Deva University of Agriculture and Technology, Kumarganj, Faizabad-224229 \\ (U.P.), INDIA \\ ${ }^{2}$ Central Institute of Freshwater Aquaculture (CIFA), Kaushalyaganga, Bhubaneswar-751002 (Orissa), INDIA \\ *Corresponding author. Email: vermalp@yahoo.com
}

Received: December 26, 2014; Revised received: June 8, 2015; Accepted: July 24, 2015

\begin{abstract}
Probiotics are known to improve the growth rate of aquatic organisms. Little experimentation has focused on supplementation of live colony forming units of L.sporogenes in Cirrhinus mrigala to access the growth performance. A feeding trial was conducted for 50 days to study the effects of Lactobacillus sporogenes on growth and body composition of Cirrhinus mrigala (Hamilton-Buchnan, 1822) fingerlings. Fishes were fed with five experimental feeds containing $3.31 \times 10^{5}$ colony forming units (CFU)/100g-1 of $L$. sporogenes in diet $D_{2}, 1.65 \times 10^{6}$ CFU/ $100 \mathrm{~g}^{-1}$ in diet $\mathrm{D}_{3}, 3.31 \times 10^{6} \mathrm{CFU} / 100 \mathrm{~g}^{-1}$ in diet $\mathrm{D}_{4}$ and $4.96 \times 10^{6} \mathrm{CFU} / 100 \mathrm{~g}^{-1}$ in diet $\mathrm{D}_{5}$. Control diet $\mathrm{D}_{1}$ was kept devoid of $L$. sporogenes. The diets prepared were containing $0.0 \%\left(D_{1}\right), 0.1 \%\left(D_{2}\right), 0.5 \%\left(D_{3}\right), 1.0 \%\left(D_{4}\right)$ and $1.5 \%$ $\left(D_{5}\right)$ of live cells of $L$. sporogenes CFU/100gm- ${ }^{1}$ of feed. Increasing trend of weight gain, specific growth rate (SGR), protein efficiency ratio (PER) improved food conversion ratio (FCR) was observed in treatments fed with probiotic added feeds than control feed. Best growth performance was found in the treatment fed with $\mathrm{D}_{4}$ of $L$. sporogenes containing $3.31 \times 10^{6} \mathrm{CFU} 100 \mathrm{~g}^{-1}$ of feed. At increased level $4.96 \times 10^{6} \mathrm{CFU} 100 \mathrm{~g}^{-1}$ of $\mathrm{L}$. sporogenes inclusion the growth performance was dropped. Tissue protein content was also observed to be higher in animals fed with $D_{4}$ feed. The lipid content was significantly $(P<0.05)$ higher in fingerlings fed with control feed $\left(D_{1}\right)$. In short, $L$. sporogenes addition to a level of $3.31 \times 10^{6} \mathrm{CFU} 100 \mathrm{~g}^{-1}$ in feed improved growth performance of C. mrigala fingerlings. Therefore, it is evident that $3.31 \times 10^{6} \mathrm{CFU} 100 \mathrm{~g}^{-1}$ of feed of $L$. sporogenes can be considered as suitable concentration for attaining good growth in C.mrigala fingerlings.
\end{abstract}

Keywords: Bacteria, C. mrigala, Growth performance, L. sporogenes, Probiotics

\section{INTRODUCTION}

Aquaculture is currently the fastest growing animal production sector in the world, expanding at an average annual rate of $8-11 \%$ since 1984 (Pike and Barlow, 2002; FAO, 2006). In fish farming, nutrition is critical because feed represents $60 \%-71 \%$ of the production costs (De Silva, 1985), thus fish nutrition investigations are mainly directed towards reducing feed cost by manipulating the feed formulation. To reduce the cost and to improve the performance a number of feed additives inclusive of micro-organisms have been tested in aquaculture, some of the most utilized growth promoting additives includes hormones, antibiotics, ionophores and some salt (Klaenhammer and Kullen, 1999). During last decade, use of chemical drugs especially antibiotics have become limited due to development of resistant strains of certain pathogens (Lara-Flores et al., 2003; Nihan et al., 2013). Presence of residues of certain antibiotics in aquaculture products may also cause intestinal disorders and problems to human health (WHO, 2006). Probiotics have been identified as live microorganisms colonized in the intestine and/or animal originated microbial supplements could effected fish health by improving the intestinal microbial balance (Wang and Wang, 2008; Dimitroglou et al., 2011). As an alternative to growth promoting antibiotics probiotics have been used in feed supplementations. Probiotics improves the growth rate in aquatic animals without causing any residual effect to human health unlike antibiotics. Lactobacillus species are one among the most commonly used microbes for nutritional and enzymatic contribution to the digestion process in animals (Suzer et al., 2008; Ganguly et al., 2010). Gatesoupe (1999) mentioned that indigenous beneficial bacterial strains isolation and multiplication for further use in aquaculture is desirable. However, isolation of indigenous species -specific microorganism from fish and its subsequent multiplication to use under farm conditions is difficult (Prasad et al., 2013). Little experimentation has focused directly on supplementation of non indigenous probiotic microbes in freshwater fishes. In present study 50 days feeding trial was conducted to evaluate the effect of exogenous $L$. sporogenes live colony forming units of on growth and body composition of 
C. mrigala fingerlings. It was observed that supplementation of L.sporogenes improves the growth performance of C.mrigala fingerlings and the counts of colony forming units in feed decreased with the increasing feed storage duration. Since probiotics are known to effectively improve growth performance of host organisms, in the present work an attempt has been made to identify an optimal concentration of $L$. sporogenes for attaining good growth and their concentration of biochemical constitutes in C. mrigala fingerlings through prepared feed.

\section{MATERIALS AND METHODS}

Experimental rearing of $C$. mrigala fingerlings: Induced bred $C$. mrigala fingerlings were obtained from Central Institute of Freshwater Aquaculture (CIFA), Orissa, India. The fingerlings were acclimatized for twelve days. During acclimatization period they were fed with control diet and supplied with round the clock aeration from a compressed air pump. After acclimatization $C$. mrigala fingerlings (average weight $2.54 \pm .038 \mathrm{~g}$ ) were introduced into fifteen uniform size rectangular containers.

Fifteen fishes of uniform size were kept in each treatment container following a completely randomized design (CRD). Fishes were fed with five experimental feeds containing $3.31 \times 10^{5}$ colony forming units (CFU) $/ 100 \mathrm{~g}^{-1}$ of $L$. sporogenes in diet $\mathrm{D}_{2}, 1.65 \times 10^{6}$ $\mathrm{CFU} / 100 \mathrm{~g}^{-1}$ in $\operatorname{diet} \mathrm{D}_{3}, 3.31 \times 10^{6} \mathrm{CFU} / 100 \mathrm{~g}^{-1}$ in $\operatorname{diet} \mathrm{D}_{4}$ and $4.96 \times 10^{6} \mathrm{CFU} / 100 \mathrm{~g}^{-1}$ in diet $\mathrm{D}_{5}$. Control diet $\mathrm{D}_{1}$ was kept devoid of $L$. sporogenes. Three replicates were used for each feeding scheme. The total volume of water in each container was maintained at 30 liters throughout the experimental period. Aeration was continuously provided to all containers. The containers were cleaned daily and $25 \%$ of water was replaced on alternate days with mature bore well water. Water temperature, $\mathrm{pH}$, dissolved oxygen, free carbon-dioxide, carbonate hardness were recorded once a week following methods suggested by APHA (1995).

Preparation of feed: The compositions of experimental diets are given in table 1. Feed ingredients were finely powdered and thoroughly mixed with water to make dough. The dough was then steam cooked for twenty minutes in autoclave. The vitamin and mineral premix was added homogeneously after cooling the dough. The bacterial cultures harvested, washed were also added to the dough before pelleting. The bacterial culture supplement was prepared in the following way; One gram of lyophilized L. sporogenes was suspended in a liter of De man Rogsa and Sharpe (MRS) broth (Hi-Media, Mumbai, India) and kept was for incubation. After 24 hours, the culture was centrifuged at 5000 rpm in a refrigerated centrifuge (Remi, Mumbai, India) to obtain a pellet. The pellet was then washed twice with normal saline $(0.85 \%)$ and weighed. Required portions of the pellets were added to the feeds at different levels of bacteria. A portion $(0.1 \mathrm{~g})$ of the feed pellet was then suspended in $10 \mathrm{ml}$ of sterile normal saline $(0.85 \%)$. To find out the number of colony forming units of $L$. sporogenes present per gram of feed, $0.1 \mathrm{ml}$ of this serially diluted sample were pelleted on MRS agar following spread plate technique. The number of live bacteria added to each category of feed was calculated from the enumerated sample as per gram of feed. The required amounts by weight of $L$. sporogenes were mixed in four different diets replacing the equal amount of rice bran. The dough prepared was pressed in a hand pelletizer to get feed of $1.5 \mathrm{~mm}$ diameter. The feeds were dried in a hot air oven at $45^{\circ} \mathrm{C}$ overnight and were stored at $4^{\circ} \mathrm{C}$ in air tight containers until used. The pellets were crumbled before being dispensed. The curdling test was done on every $15^{\text {th }}$ days by addition of $L$. sporogenes containing feeds in sterilized milk as suggested by Hugenholtz (1993).

Biochemical analysis: Proximate compositions of the fingerlings of $C$. mrigala (Caracass) and the feeds were analyzed for their proximate composition following standard methods (AOAC, 1995) in Nutrition and Biochemistry Laboratory of CIFA. Feed ingredients, experimental diets samples and fish carcass were analyzed for proximate composition according to AOAC (1995) procedures as follows: Moisture was determined by oven drying at $105^{\circ} \mathrm{C}$ for 24 hours; crude protein $($ Nitrogen $\times 6.25)$ by micro Kjeldahl digestion and distillation after acid digestion; lipid was determined by extracting the residue with $40-60^{\circ} \mathrm{C}$ petroleum ether as a solvent for 7-8 hours in a Soxhlet apparatus; and ash was determined by ignition at $550^{\circ}$ $\mathrm{C}$ in a Muffle furnace to constant weight. Total carbohydrate was calculated by subtracting the value of protein, fat, moisture and ash from the total weight and expressed in percentage as described by Halver (1976). The values were expressed as percentage of the sample analyzed. The proximate analysis of the carcasses was done before the initiation and after termination of the experiment.

Screening of native bacteria for presence of lactic acid bacteria: To establish whether the $L$. sporogenes bacteria are autochthonous micro-flora of C. mrigala, intestine samples were weighed and homogenized in sterile saline and plated both on MRS agar and on nonselective agar (Soybean casein digest agar). The representative colonies were biochemically analyzed to find if any isolate resembled with the lactic acid bacteria.

Growth study: Fish performance in terms of weight gain (\%), SGR, FCR, protein efficiency ratio (PER) and apparent net protein utilization (ANPU, \%) was calculated using the following formulae:

Weight gain $(\%)=[($ Final body weight - Initial body weight $)] \times 100 ; \mathrm{SGR}=[(\ln \mathrm{Wt}-\ln \mathrm{Wi}) / \mathrm{T}] \times 100$; where $\mathrm{Wt}$ is the final weight of fish at the time of termination of experiment, Wi is initial weight of fish at the time of start of experiment, and $\mathrm{T}$ is the culture period in days; FCR $=$ Feed consumed/Weight gain, 
PER $=$ Weight gain $/$ Protein intake; ANPU $\%=($ Net increase

carcass protein / Protein consumed) $\times 100$.

Statistical analysis: The data was statistically analyzed using statistical software (SPSS version 11.0). One way analysis of variance (ANOVA) and Duncan's multiple range test (Duncan, 1955) were applied to compare means between two treatments.

\section{RESULTS AND DISCUSSION}

Biochemical composition of feeds: The biochemical compositions of experimental diets are presented in table 2. Protein content of the diets was varying between $31.31 .60 \pm 0.04$ to $31.62 \pm 0.04$ percent. Lipid

Table 1. Composition of diet ingredients (\% dry weight).

\begin{tabular}{ll}
\hline Ingredients & Amount \% \\
\hline Ground nut oil cake & 40 \\
Wheat flour & 16 \\
Soybean oil cake & 15 \\
Rice bran & 12.5 \\
Fish meal & 10 \\
Fish oil & 4.5 \\
*Vit-mineral mix & 1.0 \\
Carboxymethylcellulose & 1.0 \\
\hline
\end{tabular}

*Vitamins and minerals mixture added in the experimental diets. content varied between $5.63 \pm 0.03$ to $5.66 \pm 0.01$. The diets prepared were statistically similar to their protein, lipid and carbohydrate content.

Viability of $\boldsymbol{L}$. sporogenes in feed: The Lactobacillus, Bacillus and yeast micro-organisms have been used as probiotics, in crustacean and fish culture (Gomezgil, 1995; Rengpipat et al., 2000; Hong et al., 2005; Pooramini et al., 2009; Boonthai et al.) Uma (1995), Gabriel, et al., (2002) Venkat, et al (2004) Seenivasan, et al, (2012) have also reported effectiveness of commercially available probiotics to improve growth performance of different crustaceans and fin fishes. The, degree of survivability of probiotic bacteria in the experimental feeds is an important criterion to assess their effect on growth performance of host. In the present study all experimental feeds, when inoculated in sterilized skim milk broth were able to curdled milk within 24-48 hours indicated the presence of $L$. sporogenes in feed which was also confirmed using microscopic examinations. Milk curdling test indicate all the test diet containing L. sporogenes were viable till $30^{\text {th }}$ day. Curd formation by Lactic Acid Bacillus (LAB) results in formation of plain curd with sweet aroma and the curd formation by other bacteria is characterized by bad odour, presence of flakes and with different consistencies (Molimard and Spinnler, 1996). It was observed that the curding of skimmed milk agar occurred till $30^{\text {th }}$ day, the colony forming

Table 2. Proximate composition (mean \pm SD) of diet on $\%$ dry weight basis.

\begin{tabular}{lccccc}
\hline $\begin{array}{l}\text { Proximate } \\
\text { composition (\%) }\end{array}$ & $\mathbf{D}_{\mathbf{1}}$ & $\mathbf{D}_{\mathbf{2}}$ & $\mathbf{D}_{\mathbf{3}}$ & $\mathbf{D}_{\mathbf{4}}$ & $\mathbf{D}_{\mathbf{5}}$ \\
\hline Crude protein & $31.62 \pm 0.04$ & $31.61 \pm 0.02$ & $31.6 \pm 0.03$ & $31.61 \pm 0.02$ & $31.61 \pm 0.02$ \\
Crude lipid & $5.65 \pm 0.50$ & $5.66 \pm 0.01$ & $5.65 \pm 0.01$ & $5.66 \pm 0.02$ & $5.63 \pm 0.03$ \\
Carbohydrate & $48.25 \pm 0.31$ & $48.37 \pm 0.24$ & $48.29 \pm 0.52$ & $48.31 \pm 0.66$ & $48.29 \pm 0.57$ \\
Ash & $14.37 \pm 0.21$ & $14.23 \pm 0.25$ & $14.27 \pm 0.30$ & $14.28 \pm 0.17$ & $14.30 \pm 0.10$ \\
Energy (kcal/100g) & $371.94 \pm 0.72$ & $371.98 \pm 0.45$ & $371.90 \pm 0.85$ & $371.91 \pm .04$ & $371.83 \pm 0.14$ \\
\hline
\end{tabular}

Table 3. L. sporogenes counts in different diet after 15 days interval.

\begin{tabular}{cccccc}
\hline Days & $\mathbf{D}_{\mathbf{1}}$ & $\mathbf{D}_{\mathbf{2}}$ & $\mathbf{D}_{\mathbf{3}}$ & $\mathbf{D}_{\mathbf{4}}$ & $\mathbf{D}_{\mathbf{5}}$ \\
\hline CFU/100g $\pm \mathrm{SD}$ & 0.0 & $3.31 \times 10^{5}$ & $1.65 \times 10^{6}$ & $3.31 \times 10^{6}$ & $4.96 \times 10^{6}$ \\
$15(\%$ survival) & 0.0 & $67.01 \pm 1.21$ & $67.67 \pm 3.87$ & $67.51 \pm 3.41$ & $67.56 \pm 3.11$ \\
30 (\%survival) & 0.0 & $46.90 \pm 2.18$ & $46.77 \pm 3.72$ & $46.96 \pm 4.40$ & $46.75 \pm 1.97$ \\
\hline
\end{tabular}

Table 4. Proximate composition of C. mrigala (\% dry matter basis) tissues fed with $L$. sporogenes supplemented diets and control diets.

\begin{tabular}{llllll}
\hline $\begin{array}{l}\text { Proximate } \\
\text { composition(\%) }\end{array}$ & \multicolumn{1}{c}{$\mathbf{D}_{\mathbf{1}}$} & \multicolumn{1}{c}{$\mathbf{D}_{\mathbf{2}}$} & $\mathbf{D}_{\mathbf{3}}$ & $\mathbf{D}_{\mathbf{4}}$ & $\mathbf{D}_{\mathbf{5}}$ \\
\hline Moisture & $76.34 \pm 1.62$ & $77.29 \pm 0.64$ & $77.54 \pm 1.10$ & $77.54 \pm 0.58$ & $77.62 \pm 0.46$ \\
$\mathrm{CP}$ & $57.77^{\mathrm{a}} \pm 0.03$ & $57.78^{\mathrm{a}} \pm 0.05$ & $57.87^{\mathrm{ab}} \pm 0.06$ & $58.00^{\mathrm{b}} \pm 0.12$ & $57.79^{\mathrm{a}} \pm 0.08$ \\
$\mathrm{EE}$ & $6.60^{\mathrm{c}} \pm 0.42$ & $6.38^{\mathrm{c}} \pm 0.66$ & $5.82^{\mathrm{b}} \pm 0.41$ & $5.26^{\mathrm{a}} \pm 0.14$ & $5.17^{\mathrm{a}} \pm 0.03$ \\
Ash & $16.55 \pm 0.26$ & $16.47 \pm 0.20$ & $17.57 \pm 0.26$ & $16.50 \pm 0.32$ & $16.54 \pm 0.29$ \\
TC & $19.06^{\mathrm{a}} \pm 0.65$ & $19.35^{\mathrm{a}} \pm 0.18$ & $19.80^{\mathrm{ab}} \pm 0.14$ & $20.36^{\mathrm{b}} \pm 0.41$ & $20.48^{\mathrm{b}} \pm 0.34$ \\
OM & $83.44 \pm 0.26$ & $83.52 \pm 0.20$ & $83.42 \pm 0.26$ & $83.50 \pm 0.32$ & $84.45 \pm 0.30$ \\
Energy (Kcal/100g) & $366.79^{\mathrm{c}} \pm 1.31$ & $366.01^{\mathrm{bc}} \pm 1.12$ & $362.81^{\mathrm{ab}} \pm 1.22$ & $360.30^{\mathrm{a}} \pm 1.22$ & $359.11^{\mathrm{a}} \pm 1.11$ \\
\hline
\end{tabular}

*Values with identical superscript letters in the same row are not significantly different $(\mathrm{p}<0.05)$, OM - Organic matter $=100$ -Ash, $\mathrm{CP}$ - Crude protein $=(\mathrm{N} \% x 6.25)$, EE- Ether extract, $\mathrm{TC}=$ Total carbohydrate 
Table 5. Growth performance of $C$. mrigala fingerlings fed experimental diets for 50 days (mean $\pm \mathrm{SD}$ ) supplemented with $L$. sporogenes supplemented diets.

\begin{tabular}{llllll}
\hline Performance & \multicolumn{1}{c}{$\mathbf{D}_{\mathbf{1}}$} & \multicolumn{1}{c}{$\mathbf{D}_{\mathbf{2}}$} & \multicolumn{1}{c}{$\mathbf{D}_{\mathbf{3}}$} & \multicolumn{1}{c}{$\mathbf{D}_{\mathbf{4}}$} & \multicolumn{1}{c}{$\mathbf{D}_{\mathbf{5}}$} \\
\hline Initial weight (g) & $2.56 \pm 0.04$ & $2.55 \pm 0.05$ & $2.53 \pm 0.01$ & $2.52 \pm 0.02$ & $2.51 \pm 0.04$ \\
Final weight (g) & $5.57^{\mathrm{a}} \pm 0.04$ & $5.78^{\mathrm{b}} \pm 0.02$ & $5.90^{\mathrm{c}} \pm 0.02$ & $5.89^{\mathrm{c}} \pm 0.01$ & $5.59^{\mathrm{a}} \pm 0.02$ \\
Live weight gain (\%) & $117.58^{\mathrm{a}} \pm 2.09$ & $119.50^{\mathrm{ab}} \pm 1.39$ & $133.34^{\mathrm{c}} \pm 1.58$ & $133.89^{\mathrm{c}} \pm 3.07$ & $122.44^{\mathrm{b}} \pm 2.80$ \\
SGR (\% per day) & $1.55^{\mathrm{a}} \pm 0.02$ & $1.63^{\mathrm{b}} \pm 0.04$ & $1.69^{\mathrm{c}} \pm 0.01$ & $1.70^{\mathrm{c}} \pm 0.02$ & $1.60^{\mathrm{ab}} \pm 0.02$ \\
FCR & $2.36^{\mathrm{b}} \pm 0.04$ & $2.30^{\mathrm{b}} \pm 0.03$ & $2.12^{\mathrm{a}} \pm 0.01$ & $2.11^{\mathrm{a}} \pm 0.05$ & $2.31^{\mathrm{b}} \pm 0.04$ \\
PER & $1.33^{\mathrm{a}} \pm 0.02$ & $1.37^{\mathrm{a}} \pm 0.02$ & $1.49^{\mathrm{b}} \pm 0.01$ & $1.50^{\mathrm{b}} \pm 0.03$ & $1.37^{\mathrm{a}} \pm 0.02$ \\
ANPU & $29.84^{\mathrm{a}} \pm 1.94$ & $29.85^{\mathrm{a}} \pm 1.89$ & $34.38^{\mathrm{ab}} \pm 2.69$ & $40.19^{\mathrm{b}} \pm 5.72$ & $30.95 \pm 3.61$ \\
Survival (\%) & 100 & 100 & 100 & 100 & 100 \\
\hline
\end{tabular}

*Values with identical superscript letters in the same row are significantly different $(p<0.05)$

units were of $L$. sporogenes in the feeds reduced. On the day of preparation ( $0^{\text {th }}$ day), the viable counts of $L$. sporogenes were $3.31 \times 10^{5}, 1.65 \times 10^{6}, 3.31 \times 10^{6}$, $4.96 \times 10^{6} \mathrm{CFU}_{100 \mathrm{~g}^{-1}}$ in $\mathrm{D}_{2}, \mathrm{D}_{3}, \mathrm{D}_{4}$ and $\mathrm{D}_{5}$ feeds, respectively. The $\mathrm{D}_{1}$ (Control feed) did not curdle the media and when plated did not have L. sporogenes. The percent counts of $L$. sporogenes present after 15 and 30 days of feed preparation were are presented in table 3 .

In the present study the CFU of $L$. sporogenes decreased up to 76.96 percent on $30^{\text {th }}$ day of feed preparation, which shows that CFU in the feeds reduces as the storage life of feed increases. Similar to our observations Gabriel et al. (2002) also observed reduced counts of agglomerated $S$. cerevisiae in the fine sphere pelleted shrimp feed were slightly higher $\left(1.6 \times 10^{10} \mathrm{CFU} / \mathrm{g}\right.$ and $1.3 \times 10^{10}$ cells/ g) than the large spheres $\left(8 \times 10^{9} \mathrm{CFU} / \mathrm{g}\right.$ and $8.2 \times 10^{9}$ cells $\left./ \mathrm{g}\right)$ pelleted shrimp feeds. Gabriel et al (2002) mentioned that the level of reduction may vary according to the procedure applied to prepare the feed pellet, shear force and temperature and moisture level used for drying. Venkat et al. (2004) reported survival of L.plantarum in feed till 60 days but they have not reported the change in number of added probiotics. Similarly, Prasad et al. (2013) also reported reduced counts of S.cerevisae by $34.44 \%$ by $30^{\text {th }}$ day in pelleted feed and best growth performance were observed in M.rosenbergii post larvae at CFU concentration of $65.83 \times 10^{3} \mathrm{CFU} / 100 \mathrm{~g}$ of feed.

Water quality parameters: During the experiment water quality parameters like water temperature ranged 29.0-31 ${ }^{0} \mathrm{C}$, dissolved oxygen level was 5.3.0-6.8 mg/1 and total alkalinity as $\mathrm{mg} \mathrm{CaCO}_{3} \mathrm{l}^{-1}$ ranged between 126-128, total hardness as $\mathrm{mg} \mathrm{CaCO}_{3} \mathrm{l}^{-1}$ ranged from 110-116. Ammonia $\left(\mathrm{NH}_{3}\right)$ level ranged 0.22-0.37 mg/l, while nitrate-N ranged from $0.19-0.27 \mathrm{mg} / \mathrm{l}$. Nitrite-N and $\mathrm{PO}_{4}$ were observed in the optimum range of 0.01 $-0.03 \mathrm{mg} / \mathrm{l}$ and $0.45-0.68 \mathrm{mg} / \mathrm{l}$, respectively. There was no significant change observed in the water quality in the test or control diet rearing tanks. Similar to our observations Ventak et al., (2004) also reported significant higher growth rate, feed efficiency ratio, protein efficiency ratio were recorded in M.rosenbergii post larvae when bioencapsulated L.sporogenes were fed through Artemia.

Gut screening for $\boldsymbol{L}$. sporogenes: Before start of feeding trial intestinal bacterial isolates were subjected to series of biochemical tests comprising of gram staining, catalase, indole, motility, Methyl Red VogesProskauer (MRVP), citrate utilization, oxidase, and glucose, mannitol, sucrose, lactose utilization were performed to find out if $L$. sporogenes are indigenous micro-flora of $C$. mrigala fingerlings. The colony characteristics and biochemical tests performed showed that $L$. sporogenes is not present in the indigenous micro-flora of $C$. mrigala fingerlings. In our study dominant genera identified were Aeromonas spp., Pseudomonas spp. and Streptococcus spp., Enterobacter spp., Bacillus spp. Similar kind of micro-flora in aquatic organisms have been also reported by Sivakami et al. ( 1996) in Indian major carps and Al-Harbi and Uddin et al. (2005) in Oreochromis niloticus. The higher prevalence of A.hydrophila, Pseudomonas Streptococcus and Enterobacter species in the study period suggests that these bacteria may be common bacterial species in the ponds. The bacterial flora of the water may vary with the feeding rates (Tucker, 1985) and with the variation in nutrient load (Buras et al. 1987) in the pond. The bacterial composition may also vary from species to species and from one environment to another environment. (Nayak,2010).

Carcass composition and growth performance: Biochemical compositions of the fingerlings are presented in table 4 . Significantly higher $(p<0.05)$ carcass protein was

recorded in fingerlings fed with $\mathrm{D}_{3}$ and $\mathrm{D}_{4}$ feed. Lowest protein was recorded in fingerlings fed with control feed $\mathrm{D}_{1}(57.77 \%)$. Lowest lipid content was observed in $C$. mrigala fingerlings fed with $\mathrm{D}_{4}$ feed $(5.26 \%)$ and significantly higher $(\mathrm{p}<0.05)$ lipid content $(6.60 \%)$ was found in treatment fed with $\mathrm{D}_{1}$ control feed. Moisture content was minimum $(76.34 \%)$ in treatment fed with $\mathrm{D}_{1}$ feed and maximum in treatment fed with $\mathrm{D}_{5}$ $(77.62 \%)$ feed. No specific trend and significant difference was observed for ash and organic matter content among treatments.

Son et al.,(2009) also reported that significant increase 
in percent weight gain (PWG) of $404.6 \%$, and feed efficiency (FE) of 1.26 respectively of grouper Epinephelus coioides when fed a diet containing $L$. plantarum at the levels $10^{8} \mathrm{CFU} \mathrm{kg}^{-1}$. Parthasarathy and Ravi ( 2011) reported best growth rate, feed utilization and survival rate in Catla catla when fed with commercial fish feed containing $10^{7} \mathrm{CFU}$ of $L$. plantarum per gram of feed. In the present study we also observed $12.39 \%$ higher live weight gain percent with $\mathrm{D}_{4}$ fed diets containing $3.31 \times 10^{6} \mathrm{CFU} / 100 \mathrm{~g}$ of feed than control feed. The better growth performance by $\mathrm{D}_{4}$ diet fed fingerlings may be because of better role played by Lactobacillus spp. as beneficial flora in the gastrointestinal tract among others include: production of antimicrobial substances; enhancement of the immune response and improve resistance of fish against bacterial pathogens; increase of availability of nutrients and use of some non-digestible carbohydrates (Dimitroglou et al., 2011).

In the present study we observed improved growth of C. mrigala fingerlings as results of feeding the live colony forming units of $L$. sporogenes through prepared feed. Highest weight gain percent, SGR, PER, and ANPU and lowest FCR were obtained in fingerlings fed with $\mathrm{D}_{4}$ feed (Table 5). However, no significant difference $(\mathrm{P}<0.05)$ in weight gain percentage, SGR, PER, and ANPU and FCR were recorded between fingerlings reared with $\mathrm{D}_{4}$ and $\mathrm{D}_{3}$ feed. Treatments fed with $\mathrm{D}_{2}$ and $\mathrm{D}_{5}$ feeds also resulted in better performance than those fed with $\mathrm{D}_{1}$ (control) feed. Fingerlings reared with highest inclusion level $\left(\mathrm{D}_{5}\right)$ of L. sporogenes resulted in reduced performance as compared with the other test feeds. $100 \%$ survival was obtained in all the treatments including control. The beneficial effects of probiotics in aquatic organisms have been documented by Charlon and Bergot (1984) in common carp (Cyprinus carpio), Gatesoupe (1991) in turbot (Scopthalamus ) larvae, Gomezgil (1995) in shrimp (P. monodon) larvae and Seenivasan et al. (2012) in freshwater prawn (M. rosenbergii). Probiotics are used aquaculture to manipulate the microbial population of the aquatic environment and to mitigate or eliminate pathogenic microorganisms, thereby leading to better growth and survival of the cultured species (Irianto and Austin, 2002).

In control group percent per day weight gain was lower than other treatment groups. Best percent live weight gain were obtained in the fingerlings reared with $3.31 \times 10^{6} \mathrm{CFU} / 100 \mathrm{~g}^{-1}$ of probiotics added feed gives an impression that the probiotic effect is best achieved at this level. Which is also analyzed by drawing parallel changes with other parameters like SGR, FCR, PER and ANPU (Table 5). The PER and ANPU results indicate that supplementing feeds with probiotics significantly improves the protein utilization capacity of C. mrigala fingerlings. Ramakrishnan et al. (2008) observed improved survival, growth, feed conversion ratio, protein efficiency ratio in common carp (Cyprinus carpio) fed with probiotics and spirulina. Improved protein digestibility upon addition of $L$. acidophilus have also been reported by Lara-Flores et al. (2003) in Nile tilapia. Similar results of improved growth and survival of Penaeus indicus larvae were observed when Lactobacillus plantarum were added in rearing medium by Uma et al. (1999). Venkat et al. (2004) also observed improved growth and feed conversion efficiency when bio-encapsulated $L$. sporogenes were fed to $M$. rosenbergii through Artemia. Douillet and Langdon (1994) used bacteria strain CA2 at $1 \times 105 \mathrm{CFU} / \mathrm{ml}$ to increase growth of Crassostrea gigas larvae. Similar observations of enhanced growth in Pacific oysters $(C$. gigas) have been reported by Douillet and Langdon (1994). Subhash and Lipton (2007) also reported that L.acidophilus supplemented diets showed significantly higher survival ( $78.7 \pm 8.1$ and $85.7 \pm 2.9 \%$, respectively) than the control groups $(60.7 \pm 1.2 \%)$ in P.margaritifera. Best PER and ANPU obtained at 1\% probiotic inclusion level contributes to optimizing protein use for growth, a significant quality protein being the most expensive feed nutrient. Reduced weight gain, SGR, PER were observed when the inclusion level of $L$. sporogenes colony forming units was raised to $1.5 \%$. The reduced growth at higher inclusion level of $L$. sporogenes may be because of increased catabolic effect and reduced digestion efficiency in C. mrigala fingerlings. Ghosh et al. (2004) also reported reduced live weight gain percentage in Rohu (Labeo rohita) fingerlings when $L$. acidophilus was fed at higher level through pelleted feed. Similar observations have been documented by Uma et al. (1999) in P. indicus. Better efficiency of protein uptake may be due to better digestion and assimilation of the nutrients in the gut by the supplemented micro-flora possibly by virtue of extra cellular enzymes that play an important role in the digestion process as observed in turbot larvae (Munilla et al., 1990). No mortality was observed in any of the experimental group this may be due to the favorable range of environmental parameters in all the treatments. This also indicates that $L$. sporogenes when fed through feed do not have adverse impact on survival of C. mrigala. The possible reason for the overall growth response in C.mrigala may be because of increased digestibility due to presence of $L$. sporogenes, which ultimately lead to increased absorption as reported by Douillet and Langdon, (1993) and Uma et al., (1999) in the oyster, Crassostrea gigas and the shrimp, $P$. indicus respectively. Improved feed utilization by probiotic supplementation have extensively been reported in aquaculture species (Suralikar and Sahu, 2001; Lara-Flores et al., 2003; Ziaei-Nejad et al., 2006; Shinde et al., 2008). Increased growth may also be attributed due to vitamins as lactic acid bacteria are reportedly produced B-complex vitamins in the gut of 
aquaculture animals (Goldin and Gorbach, 1992; Mondal et al., 2003; Abraham et al., 2007).

\section{Conclusion}

The present study concluded that commercially available non-indigenous L. sporogenes can be used as feed additives for C.mrigala fingerlings. When viable culture of L.sporogenes are added it feed their viability must be regularly monitored as increased duration of feed storage results in reduced counts of added CFU of probiotics. C.migala fingerlings showed best growth performance in terms of increased live weight gain $(133.89 \pm 34 \%)$, specific growth rate $(1.70 \pm 0.02 \%)$, apparent net protein utilization $(40.19 \pm 5.72 \%)$, protein efficiency ratio $(1.50 \pm 0.03)$ and decreased food conversion ratio $(2.11 \pm 0.05)$ at inclusion level of $3.31 \times 10^{6} \mathrm{CFU} / 100 \mathrm{~g}^{-1}$. Probiotics improve the growth rate of fish and therefore can be used as feed additives. Further studies are required to elucidate their commercial application in aquaculture.

\section{ACKNOWLEDGEMENTS}

Authors are thankful to Director of Central Institute of Freshwater Aquaculture, Bhubaneswar, Orissa, India, for providing facility and Indian Council of Agricultural Research for financial assistance to carry out this work.

\section{REFERENCES}

Al-Harbi, H.A. and Uddin, N. (2005). Bacterial diversity of tilapia (Oreochromis niloticus) cultured in brackish water in Saudi Arabia. Aquaculture, 250:566-572.

AOAC (1995). In: W. Horwitz (ed.).Official Methods of Analysis of the Association of Official Analytical Chemist (AOAC). $16^{\text {th }}$ ed. AOAC Int. Arlington VA.

APHA (1995). Standard Methods for Examination of Water and Wastewater. $19^{\text {th }}$ ed. American Water Works Assoc. and Water Pollut. Control Fed., Am. Public Health Assoc., New York.

Boonthai, T., Vuthhiphandchai, V. and Nimrat, S. (2011). Probiotic bacteria effects on growth and bacterial composition of black tiger shrimp (Penaus monodon). Aquacult. Nutr., 17(6): 634-644.

Buras, N., L. Duek, S. Niv, B. Hepher, and Sandbank. E. (1987). Microbiological aspects of fish grown in treated wastewater. Water Resources, 21:1-10.

Charlon, N. and Bergot, P. (1984). Rearing system for feeding fish larvae on dry diets, trial with carps (Cyprinus carpio L.) larvae. Aquaculture, 41:1-9.

De Silva, S.S. (1985) Performance of Oreochromis niloticus (L) fry maintained on mixed feeding schedules of different protein content. Aquaculture and Fisheries Management, 16, 331 -340.

Dimitroglou, A., Merrifield, D.L., Carnevali, O., Picchietti, S., Avella, M., Daniels, C., Guroy, Davies, S.J. (2011). Microbial manipulations to improve fish health and production-A. Mediterranean perspective. Fish and Shellfish Immunology, 30:1-16.

Douillet, P., and Langdon C.J. (1993). Effects of marine bacteria on the culture of axenic oyster Crassostrea gigas (Thunberg) larvae. Biological Bulletin, 184: 36-51.
Douillet, A.P. and Langdon, C.J. (1994). Use of a probiotic for the culture of larvae of the Pacific oyster (Crassostrea gigas, Thunberg). Aquaculture, 119: 25-40.

Duncan, D.B. (1955). Multiple range and multiple F- tests. Biometrics, (11)1-42.

FAO (Food and Agricultural Organization), (2006). The state of world fisheries and aquaculture. FAO Fisheries Technical Paper No.500.FAO, Rome, Italy 134 pp.

Gabriel, A.G., Marie, D.R. and Suarez L.E.C. (2002). Survival of agglomerated S.cerevisiae in pelleted shrimp feeds. Aquaculture, 208: 125-135.

Ganguly, S., Paul, I. and Mukhopadhayay, S.K. (2010). Application and Effectiveness of immunostimulants, probiotics, and prebiotics in aquaculture: A Review. The Israeli Journal of Aquaculture - Bamidgeh, 60 (3): 130-138.

Gatesoupe, F.J. (1991). Effect of three strains of lactic acid bacteria on the production of rotifers, Brachionus plicatilis and their dietary value for larvae turbot, Scopthalmus maximus. Aquaculture, 91: 342-353.

Gatesoupe, F.J. (1999). The use of probiotics in aquaculture. Aquaculture, 180: 147-165.

Ghosh, K., Sen, S.K. and Ray, A.K. (2004). Supplementation of Lactobacillus acidophilus in compound diet for Labeo rohita fingerlings. Indian Journal of Fisheries, 51(4): 521-526.

Gomezgil, R. (1995). The use of bacteria as probionts in shrimp larviculture. In: Larvi-95. Fish and Shellfish Larviculture, Belgium, pp.479-480.

Halver, J.E. (1976). The nutritional requirement of cultivated warm water and cold water fish species. Paper No.31. FAO. Technical Conference on Aquaculture, Kyoto, 26 May to June 9.

Hong, H.A., Duc, L.H. and Cutting, S.M. (2005). Cutting SM. The use of bacterial spore former as probiotics. FEMS Microbiol. Rev., 29: 813-835.

Hugenholtz, J. (1993). Citrate metabolism in lactic acid bacteria. FEMS Microbiology Reviews, 12: 165-178.

Irianto, A. and Austin, B. (2002). Probiotics in aquaculture. J. Fish Disease, 25: 633-642

Klaenhammer T.D. and Kullen, M.J. (1999). Selection and design of probiotics. Int. J. Food Microbiol., 50: 45-57.

Lara-Flores M., Olvera-Novoa, M.A., Guzman-Mendez, B.E. and Madrid, W.L. (2003). Use of Streptococcus faecium and Lactobacillus acidophilus, and the yeast Saccharomyces cerevisiae as growth promoters in Nile tilapia (Oreochromis niloticus). Aquaculture, 216: 193 $-201$.

Molimard, P. and Spinnler, H.E. (1996). Compounds involved in the flavor of mold-ripened cheeses: origins and properties. Journal of Dairy Science, 79: 169- 184.

Munilla-Moran, R., Stark, J.R. and Barbour, A. (1990). The role of exogenous enzymes in digestion in cultured turbot larvae (Scophthalmus maximus L.). Aquaculture, 88: $337-350$.

Nayak, S.K. (2010) Role of gastrointestinal microbiota in fish. Aquaculture Research, 41: 1553-1573

Nihan, A., Suzer, C., Gokvardar, A., Basaran, F., Coban, D., Yildirim, S., Kamaci O.H., Firat, K. and Saka, S. (2013). Effect of probiotic (Bacillus sp.) supplementation during larval development of Gilthead Sea Bream (Sparus aurata,L.) Turk. J. Fish. Aquat. Sci., 13: 407-414.

Parthasarathy, R. and Ravi, D. (2011). Probiotic bacteria as growth promoter and biocontrol agent against Aeromonas hydrophila in Catla catla (Hamilton, 1822). 
Indian J. Fish., 58(3): 87-93.

Pike, I.H. and Barlow, S.M. (2002). Impact of fish farming on fish stock. Proceeding of the Bordeaux Aquaculture and Environment Symposium, Bordeaux, France. http:// www.iffo.org.uk/tech/bordeaux.htm.

Pooramini, M., Kamali, A., Hajimoradloo, A., Alizadeh, M. and Ghorbani, R. (2009). Effect of using yeast (Saccharomyces cerevisiae) as probiotic on growth parameters, survival and carcass quality in rainbow trout Oncorhynchus mykiss fry. Int. Aquat. Res., 1: 39-44.

Prasad, L.P., Nayak, B.B., Srivastava, P.P., Reddy, A.K. and Kohli, M.P.S. (2013).Use of Brewere's yeast Saccharomyces cerevisiae as growth promoter in Giant freshwater prawn (Macrobrachium rosenbergii deMan) post larvae. Turk. J. Fish. Aquat. Sci., 13: 447-452.

Ramakrishnan, C.M., Haniffa, M.A., Manohar, M., Dhanaraj, M., Arokiaraj, A.J., Seetharaman, S. and Arun Singh, S.V. (2008). Effects of probiotics and spirulina on survival and growth of common carp (Cyprinus carpio). The Israeli Journal of Aquacultutre - Bamidgeh, 60(2): 128-133.

Rengpipat, S., Runkpratanporn, S., Piyatiratitivorakul, S. and Menasaveta, P. (2000). Immunity enhancement on black tiger shrimp (Penaeus monodon) by a probiont bacterium (Bacillus S11). Aquaculture, 191: 271-288.

Seenivasan, C., Bhavan, P.S., Radhakrishnan, S. and Shanthi, R. (2012). Enrichment of Artemia nauplii with Lactobacillus sporogenes for enhancing the survival, growth and levels of biochemical constituents in the post-larvae of the freshwater prawn Macrobrachium rosenbergii. Turkish Journal of Fisheries and Aquatic Science. 12: 23-31.

Shinde, A.N., Mulye, V.B., Chogale, N.D., Bhatkar, V.R., Bondre, R.D. and Mohite, A.S. (2008). Effect of different probiotics Macrobrachium rosenbergii (De-Man) post larvae. Aquacult, 9: 7-12.

Sivakami, R., Premkishore, G. and Chandran M.R. (1996). Occurrence and distribution of potentially pathogenic Enteriobacteriaceae in carp and pond water in Tamil Nadu, India. Aquaculture Research. 27: 375-378.

Son, V.M.,. Chang, C.C., Wu, M.C., Guu, Y.K., Chiu, C.H. and Cheng, W.T. (2009). Dietary administration of the probiotic, Lactobacillus plantarum, enhanced the growth, innate immune responses, and disease resistance of the grouper Epinephelus coioides. Fish \& Shellfish Immunology, 26(5): 691-698.

Subhash, S.K. and Lipton, A.P. (2007). Effects of a Probiotic bacterium, Lactobacillus acidophilus, on the growth and Survival of Pearl Oyster (Pinctada margaritifera) Spat. The Israeli Journal of Aquaculture - Bamidgeh. 59 (4): 201-205.

Suralikar, V. and Sahu, N.P. (2001). Effect of feeding probiotic (Lactobacillus cremoris) on growth and survival of Macrobrachium rosenbergii postlarvae. Journal of Applied Animal Research, 20: 117-124.

Suzer, C., Coban, D., Kamaci, O.H., Saka, S., Firat, K., Otgucuoglu,O. and Kucuksari, H. (2008). Lactobacillus spp. bacteria as probiotics in gilthead sea bream (Sparus aurata, L.) larvae: Effects on growth performance and digestive enzyme activities. Aquaculture. 280: 140-145.

Tucker, C.S. (1985). Water quality. Pages 141-219 in C.S. Tucker, ed. Channel Catfish Culture. Elsevier, Amsterdam, The Netherlands.

Uma, A., Abraham, T.J., Jayaseelan, M.J.P. and Sundararaj, V. (1999). Effects of probiotic feed supplementation on performance \& disease resistance on Indian White Shrimp, Penaeus indicus. J. of Aquaculture in Tropics, 14:159-164.

Venkat, H.K., Narottam, P.S. and Jain, K.K. (2004). Effect of feeding Lactobacillus-based probiotics on the gut micro-flora, growth and survival of postlarvae of Macrobrachium rosenbergii (de Man). Aquacul. Res., 35: 501-507.

Wang, Y.M. and Wang, Y.G. (2008). Advance in the mechanisms and application of micro-ecologies in aquaculture. Prog. Vet. Med., 29: 72-75 (in Chinese).

WHO, World Health Organization (2006). Report of a joint FAO/OIE/WHO expert consultation on antimicrobial use in aquaculture and antimicrobial resistance: Seoul, Republic of Korea, 13-16 June.

Ziaei-Nejad, S., Rezaei, M.H., Takami, G.A., Lovett, D.L., Mirvaghefi, A.R. and Shakouri, M. (2006). The effect of Bacillus spp. bacteria used as probiotics on digestive enzyme activity, survival and growth in the Indian white shrimp Fenneropenaeus indicus. Aquaculture, 252: 516-524. 